\title{
Institutional Determinants of Labor Reallocation in Transition
}

By: Tito Boeri and Katherine Terrell

William Davidson Working Paper Number 384

June 2001 
Forthcoming in the Journal of Economic Perspectives, Feb. 2002, Vol. 16, No. 2

\author{
Institutional Determinants of \\ Labor Reallocation in Transition*
}

Tito Boeri

IGIER-Bocconi, CEPR, and William Davidson Institute via Salasco 5, 20136 Milano

tel.: $39-02-5836.3323$

fax: $39-02-5836.3302$

and

Katherine Terrell

William Davidson Institute

University of Michigan Business School

Ann Arbor, MI 48109

tel.: $734-615-4558$

email: terrell@umich.edu

June 20, 2001

\title{
William DAVIDSON WORKING PAPER No. 384
}

* The authors would like to thank Erik Berglof, Alan Krueger, Gerard Roland, Jan Svejnar, and especially Stepan Jurajda, for useful comments on an earlier version of this paper. Francesca Mazzolari and Cristina Negrut have been invaluable in the collection of data for this paper. 


\begin{abstract}
Studying the transition means analyzing the interactions between institutions and structural change, a process we still know very little about. In this paper we show that the transition process has been very different in the countries of the Former Soviet Union (FSU) and those of Central and Eastern Europe (CEE) in terms of reallocation of labor from the old to the new sector, the extent of real wage decline and responsiveness of employment to output changes. We sift through the theoretical and empirical literature to find an explanation for these diverging adjustment trajectories and conclude that the difference can be explained in part by different policy models. The CEE countries adopted social policies that upheld wages at the bottom of the distribution and hence forced the unproductive old sector to restructure or collapse. The FSU countries allowed wages to free fall and hence did not force the hand of the old sector. Why these two models were adopted is the subject for political-economy research, however we speculate that it has to do with the relative appeal of joining the EU.
\end{abstract}

Keywords: transition economies, labor reallocation, institutions, wages JEL classification codes: $\mathrm{J} 0, \mathrm{I} 3, \mathrm{P} 3$ 


\section{Introduction}

Labor reallocation is a critical aspect of the transition process and because the experiences have been so varied, the literature can exploit a wide variation of adjustment trajectories across countries and time. On the one hand, the Central and East European countries (CEECs) are characterized by U-shaped trends of GDP and employment, and unemployment pools that are desperately stagnant in spite of the rapid structural change taking place. On the other hand, the countries of the former Soviet Union (FSU) display L-shaped patterns of GDP (with a recent upturn), marked declines in labor productivity and real wages, relatively large turnover of the unemployment pools and much less pronounced changes than in the CEECs in the reallocation of jobs between the old and the new sectors. Between these two polar cases, there are a few exceptions, such as the "Czech unemployment miracle" of the early to mid 1990s, before the recession set in and real wages increased, and the Estonian success story of the late 1990s.

How can such differences between the CEECs and FSU be explained? Initial conditions were broadly similar in that markets operated only in the shadow economy of these countries and employment was concentrated away from consumers' preferences. Heavy industry was overdeveloped, a strong small business sector was lacking, and private initiative was tolerated almost exclusively in agriculture. After the start of transition, the CEECs and FSU countries were all exposed to the collapse of trade within the Council for Mutual Economic Assistance (CMEA) and to the same set of external shocks (from the Iraqi War to the breakup of Yugoslavia). Thus, it is quite natural to attribute these asymmetric labor market trajectories to cross-country differences between the CEECs and the FSU in their economic policies and paths of institutional development.

Differences in economic policies, notably in the tightening of budget constraints of state enterprises, have been extensively characterized by the theoretical literature on transition. The models of the optimal speed of transition (OST), in particular, show that there is an optimal pace at which state sector jobs should be closed: if the government is engineering the decline of the old state sector too rapidly, then job creation in the private sector is hampered by the fiscal costs of unemployment; if the downsizing is too slow, 
then the private sector cannot take off as it will be too costly to pull workers from the old state sector. These models offer a powerful framework for understanding the macroeconomic trade-offs of transition. However, the divide between CEECs and the FSU has little to do with the alternative between rapid and gradual transition. Even within the CEECs there is significant variation in the timing of reforms. There are countries like Poland where subsidies to state enterprises were rapidly phased out, and countries, such as Hungary, which adopted a rather gradual approach in imposing financial discipline to firms.

Other institutional explanations for the asymmetries between CEECs and FSU are called into play. A large body of theory developed within the Western European context suggests that different types of social policy and labor market institutions allow for varying combinations of earnings inequality, real wage levels, elasticity of employment to output adjustments and flows of individuals across participation margins. Which kind of institutions, then, may have originated the asymmetries? Some of the early literature on transition emphasized the role of unions and insiders in conditioning the pace and characteristics of transitions. Important intellectual energy was spent devising schemes to win the resistance of insiders to restructuring, e.g., "buying-off" workers in the old sector with high unemployment benefits. It now appears that this emphasis on buy-offs was somewhat ill-placed: workers were less resistant to restructuring than anticipated. Unions were weak and highly segmented, except in specific sectors. Worker's councils had some influence at the outset of transition, but they soon lost their voice.

Much attention was also devoted to evaluating the work disincentive effects of unemployment benefit systems, which were introduced in most countries from scratch. However, the impact on wages and labor force participation of the broader package of "non-employment benefits" (involving inter alia, unemployment benefits, early retirement, liberal access to invalidity pensions, and open-ended social assistance) was not sufficiently investigated. In this paper we argue that cross regional differences in the generosity of these non-employment benefits are consistent with different trajectories of labor market adjustment in the FSU and CEE countries. Governments in the CEECs devoted proportionally more resources to non-employment benefits than their counterparts in the FSU; the higher levels of non-employment benefits in the CEECs in 
turn affected the distribution of earnings, by putting a floor to wages. One the one hand, these wage floors induced more job destruction in state enterprises, notably of unskilled workers. On the other hand, they offered income to start-up new small business activities and subsidized the growth of self-employment. However, generous non-employment benefits also put a large number of low productivity workers in long-term unemployment and encouraged large flows to inactivity.

Overall, cross-country institutional differences permit us to explain some puzzles of post-Communist labor reallocation. A key issue, which remains unanswered by our reading of the literature on labor market adjustment in the transition, is why different countries established such different labor market institutions. Further work taking a political economy perspective, such as the article by Gerard Roland in this issue of the Journal of Economic Perspectives, will have to address this question.

The plan of the paper is as follows. Section 2 documents the puzzles of transition. Section 3 reviews evidence on winners and losers. Section 4 builds on this evidence, providing tentative institutional explanations for many of the puzzles of transition. Section 5 offers a summary and evaluates pros and cons of the adjustment trajectories followed by the CEECs and the FSU.

\section{Diverging Adjustment Trajectories}

Figure 1 displays employment and output adjustment since the start of transition in the CEECs and in the FSU countries. There are marked asymmetries in the responsiveness of employment to output changes in the two groups of countries: employment adjusted to the "transitional recession" more in the first group than in the second. In spite of the steep output falls occurring in the region, the FSU group experienced a much slower decline of employment than the CEECs. Based on a series of studies reviewed by Svejnar (1999), the estimated employment-to-output elasticity for the first three years of transition ranges between 0.2-0.8 in the CEECs compared with an insignificant elasticity in Russia. While the CEECs GDP began recovering from the transitional recession in their fourth year, the FSU countries had to wait almost 10 years before experiencing a mild recovery. Significantly, employment growth is lagging behind output recovery in the CEECs, denoting strong gains in labor productivity. 
Figure 2 shows that real wages plummeted in the FSU economies (by 50\%) in the first two years of transition, twice as much as in the CEECs (25\%). Whereas wages have been recovering in the CEECs since 1991 (although in 1997 they were still 15\% below their 1989 level), they did not recover in the FSU countries (standing at about 45\% below their 1989 level). These averages of course mask variation within the two groups of countries, but the pattern is broadly similar within the two regions.

How much job reallocation has there been from the old to the new sectors in the CEECs and in the FSU? The old sector is typically characterized along three dimensions: economic activity, ownership, and firm size. In these countries employment during the communist period was concentrated in industry and away from consumer-oriented services. Employment shares in agriculture were also larger than in countries at comparable GDP per capita levels. Finally, jobs were concentrated in large conglomerations and in the public sector while non-agricultural self-employment was nonexistent or confined to the shadow economy. Hence in Table 1 we measure structural reallocation by looking at changes in employment shares from agriculture and industry to market services; from state-owned to private and from large to small enterprises and selfemployment. Two facts stand out. First, quite dramatic changes have occurred in the structure of employment over a relatively short time period. Second, structural change is proceeding at a faster pace in the CEECs than in the FSU according to most of the indicators displayed.

Whereas the CEECs, notably the countries of Visegrad, have reduced the employment share in both industry and agriculture, in the FSU, and particularly in Caucasus and Central Asian regions, most of the employment reallocation has been from industry to agriculture, as small plots offered subsistence to many poor households. The employment share of services increased by more than 10 percentage points in the CEECs and only by roughly one third of this in the FSU.

While all countries for which data are available had by 1997 more than $50 \%$ of their employment in the private sector (fourth column of Table 1), the development of a small business sector and of non-agricultural self-employment was much faster in the 
CEECs than in the FSU. By 1996, in the CEECs the shares of the workforce employed in firms with less than 100 employees reached the U.S. level in 1996 (37.9\%) and were much higher than in Russia (13.0\%). The share of non-agricultural self-employment in total employment was also 2 to 3 times larger in the CEECs than in the FSU.

Restructuring of the labor market is not frictionless, hence the last two columns in Table 1 indicate how quickly unemployment rose in these countries. The main point is that unemployment reached a peak much earlier in the CEECs than in the FSU and it was more stagnant in Central and Eastern Europe than in the countries originated from the breakup of the Soviet Empire.

Needless to say, there are asymmetries in adjustment trajectories also within these two broad groups of countries. For instance, unemployment in the Czech Republic peaked much later than in the other CEECs and the incidence of long-term unemployment has also been much less pronounced in the Czech lands than in other CEECs. Finally, Bulgaria and Romania have experienced an increase in employment in agriculture and significantly smaller increases in the share of service employment than the four Visegrad countries (Czech and Slovak Republics, Hungary and Poland).

While these within-group differences are important and should not be overlooked, the key message conveyed by Figures 1 and 2 and Table 1 is that we have at least two different labor market adjustment trajectories in the transitional arena. On the one hand, there are the CEECs experiencing significant employment adjustment, fast structural change, and high unemployment, most of which is long-term. On the other hand we have the FSU with a low responsiveness of employment to output changes, strong and persistent wage declines, slower structural change and a more gradual buildup of unemployment, which is also characterized by a relatively large turnover rate.

Where do these asymmetries come from? The theory of transition can accommodate asymmetric labor market adjustment trajectories based on differences in the policy stance. In particular, the models of the Optimal Speed of Transition (OST)

\footnotetext{
${ }^{1}$ Differences between CEECs and FSUs in the relative growth of the service sector are even more marked when the focus is on market services only, that is, personal, community and social services are not included.

${ }^{2}$ The puzzling low unemployment rates observed in Russia in the midst of output declines of the order of $50 \%$ have often been attributed to measurement problems from registry data. Administrative counts of the
} 
literature can generate a multiplicity of equilibria depending on the pace at which governments succeed in engineering mass layoffs in state enterprises. ${ }^{1}$ Consistent with the predictions of the OST literature, employment in state enterprises has been falling, unemployment increasing, and private employment increasing. However, documented differences in the pace at which this has occurred between the CEECs and FSU have little to do with the adjustment process depicted by this literature. To give an example, Russia and the Ukraine adopted much more aggressive privatization strategies than Poland or Slovenia, and yet output and employment growth in the former two have been inferior compared to the latter.

It is the key policy parameter, the key variable controlled by governments in this literature that is challenged by the evidence. Employment reductions in the state sector have only partially been driven by layoffs engineered by governments. A significant component of outflows from state sector jobs was in all countries associated with voluntary quits, not layoffs. In the early 1990s the share of layoffs to total separations was an average of 23\% in the Czech Republic (Jurajda and Terrell, 2001), 34\% in Poland (Lehmann and Wadsworth, 1999), 21\% in Slovakia (Boeri, 2000) and 25\% in Russia (Earle and Sabirianova, 2001). For comparison, ratios of job losers to the total number of separations in OECD countries typically range between 60\% and 90\% (OECD, 1997).

While the OST literature offers predictions qualitatively consistent with stock adjustment in these countries, it fails to characterize some important labor market flows and the stagnancy of transitional unemployment in the CEECs. Data from matched records across Labor Force Surveys, reported in Table 2, suggest that annual flows from employment to unemployment (Peu) have not been as sizeable as expected. ${ }^{4}$ Except for East Germany, these flows are only slightly larger than those of the U.S. in 1992-93, when it was not undergoing rapid restructuring. Significantly, an important component of employment outflows would seem to be represented in most countries by flows to inactivity (Peo or Puo). Moreover, except for the Czech Republic (until 1998) and Russia (in the first year of transition), flows leaving unemployment for a job (Pue) are small in

unemployed tend to underestimate the extent of labor slack when unemployment benefits are low.

However low unemployment rates are also found using the Labor Force Survey data.

${ }^{3}$ See Boeri (2000) for an extensive discussion of these models.

${ }^{4} \mathrm{Peu}$ is the number flowing from employment to unemployment as a proportion of the number employed. 
transition economies compared to those typically observed in the U.S. ${ }^{\text {Thus, }}$ Thus unemployment has been rapidly rising in the CEECs not because of the predicted large cohorts of workers being laid-off from state enterprises, but as a result of remarkably low outflow rates to jobs.

Another flow that is not given much importance in the OST literature is the movement from job-to-job, without an intervening spell of unemployment. ${ }^{6}$ Many of these job-to-job moves are shifts from state-sector-employment to private-sectoremployment. In Poland, for example, such job-to-job shifts were in 1992-3 more than twice as large as flows from public sector employment to unemployment: almost $9 \%$ of state sector employment moved directly to the private sector compared with a modest $4 \%$ becoming unemployed (Boeri, 2000). In the Czech Republic during the 1991-1996 period, 19\% of all those who left an old state job went directly to a new sector job, while $3 \%$ became unemployed or left the labor force (Jurajda and Terrell, 2001).

Finally, the OST model ignores the role of wages as a determinant of the level of employment in the old sector, while traditional labor demand theory argues that the levels of both wages and output determine employment. Wages are brought into play in the second phase of the OST model, but only as a function of unemployment, which is generated by government-led downsizing of the old sector. ${ }^{\square}$ However, output declines did generate employment declines in the transition economies and greater wage declines moderated these employment declines (Svejnar, 1999). Estimated elasticities of employment to changes in wages show that employment declines in the Czech Republic were lower than declines in Poland and Hungary because of the greater deterioration in wages in former Czechoslovakia (Basu et al., 1999). By extension, employment declines in the FSU were moderated by the tremendous declines in wages in that region. Hence,

\footnotetext{
${ }^{5}$ Information from registers of job-seekers also points to small outflows from unemployment to jobs in the CEECs (Boeri, 1998).

${ }^{6}$ Aghion and Blanchard (1994) model ignores this flow while Castanheira and Roland (2000) model does not.

${ }^{7}$ This is not to say that the relationship between wages and unemployment (the "wage curve") is not important, as there is a body of empirical evidence supporting this relationship in Eastern Europe (see Blanchflower, 2000 for a review). However, the estimates indicates that the wage-employment elasticities in Hungary, Poland, Russia and Slovakia are of similar size to the -0.1 found elsewhere in the world. Hence, it is not clear that this relationship can explain differences between the CEECs and the FSU adjustment trajectories.
} 
adjustment in the FSU involved wages whereas in the CEECs it involved mainly in employment.

Summarizing, the adjustment of labor markets during transition has been quite different than anticipated. In particular, it has involved in the CEECs greater employment rather than wage adjustment compared with the FSU and strikingly stagnant unemployment pools, especially when account is made of the dramatic changes occurring in the structure of employment by sector, occupation and ownership of firms. Labor market adjustment in Russia and the FSU was another story: employment hardly declined while output was plummeting, and the flows to and from unemployment displayed large turnover rates throughout the transition. Yet, changes in the structure of employment, in terms of the growth of the new small-scale private sector, were less pronounced in the FSU than in the CEECs.

Understanding why all this occurred improves our knowledge of labor reallocation in the midst of structural change. Moreover, it can help us identify the relevant policy trade-offs and the actual degrees of freedom of policy-makers in economies undergoing radical transformations. The policy trade-offs embedded in the OST literature relate mainly to the alternative between a big-bang strategy and a gradual transition process. This amounts to assuming that governments can control the pace of closure of state enterprises. However, the facts outlined above suggest that separations from state sector employment were, ultimately, an endogenous variable rather than a policy instrument, as they were to a large extent the a by-product of voluntary choices of workers. Moreover, OST theory cannot frame the trade-off between employment and wage adjustment in the old sector.

In the next two sections we survey the microeconometric literature on employment and wage adjustment in transitional economies. We will show later that its findings, coupled with information on labor market institutions in these countries, can shed some light on these puzzles. 


\section{Heterogeneity and Specificity: Winners and Losers of Transition}

A review of the microeconomic empirical literature on transition economies points to a well-defined profile of winners and losers of transition, in terms of employment and earnings mobility.

Numerous studies have identified the types of individuals that are more likely to become unemployed and to experience more difficulty in moving out of unemployment into a job. ${ }^{9}$ They generally estimate multinomial logit functions with data drawn from quarterly Labor Force Surveys regularly carried out in many countries of the CEECs. These studies show a clear pattern as to who are the winners and losers from the transition: low-educated or single individuals, and women are more likely to lose or leave their job and become unemployed. Young people are also over-represented among those flowing from employment to unemployment. However, for them it is relatively easy to find a new job while less educated, unmarried women are both more likely to become unemployed and remain unemployed longer.

This marked gender dimension of flows from employment to unemployment and vice versa can be attributed to decisions on both sides of the labor market. It can be argued that societal roles for men and women, supported by government policy, may be putting married women at a disadvantage in the labor market. For example, employers might be biased by these traditional views to favor men in hiring and women in firing. Government policies that oblige employers to provide women with rather generous maternity and child care leave (the "extended" maternity leave can last up to six years) discourage the new private sector employers, as well as state enterprises under hard budget constraints, to hire women, as they are more costly than men at the margin. Finally, a reduction in government (or enterprise) provision of free childcare in many countries is likely to have contributed to a reduction of the labor supply of married women.

A number of researchers have estimated Mincerian earnings functions using micro data in the transition economies. As shown in Table 3, studies indicate that returns to a year of education increased substantially from Communism to the early transition

\footnotetext{
${ }^{8}$ See Terrell (1999) for more details.
} 
period. 10 In these countries, a year of education raised earnings by only 2 to $5 \%$ during Communism, but, by the mid-1990s, the wage premium was between 5 and $9 \%$ per year of education, remarkably similar to the wage premia estimated for the United States and some Western European countries.

There is also an important exception among these studies, namely former East Germany (Bird et al., 1994; Krueger and Pischke, 1995) where the return to a year of schooling actually fell in the early part of the transition. A key difference between East Germany and the other transition countries is that it was forced to import labor market institutions (e.g., collective bargaining regimes) developed in the West which, by imposing high wages relative to the productivity of German firms, pushed into unemployment workers otherwise located at the lower end of the Eastern wage distribution.

Under Communism women enjoyed a higher rate of return to education. Whereas this is still true in transition, the gender gap in education premia has narrowed considerably. To give an idea of the orders of magnitudes involved, the figures in Table 3 show that in the Czech Republic, Slovakia and Russia the returns for men rose by between 75 and $117 \%$ throughout the transition, while the returns for women in these countries only rose by between $23 \%$ and $84 \%$.

Estimated returns to education in terms of premia to educational attainments, rather than years of schooling, indicate that there are significant differences in the "marketability" of the different types of education. 11 General secondary schools and tertiary education are highly and increasingly rewarded. Diplomas from lower (and in some cases also upper) vocational schools are instead very poorly "priced" by the market mechanism. Boeri (2000) and Flanagan (1993) document the over-investment made by the previous regime in this type of schooling and show that those who have received this training are over-represented in the pool of unemployed and receive wages only slightly higher than those of individuals with primary or lower educational attainments. An

\footnotetext{
${ }^{9}$ See for e.g., Jones and Kato (1997) for Bulgaria, Sorm and Terrell (2000) for the Czech Republic, King and Adamchek (1999) for Poland and Foley (1997) for Russia.

${ }^{10}$ Czech Republic (Chase, 1998; Munich et al., 1999), Poland (Rutkowski, 1997), Russia (Brainerd, 1998; Nesterova and Sabrianova, 1998), and Slovakia (Chase, 1998)

${ }^{11}$ See for e.g., Orazem and Vodopivec (1997), Munich, et al. (1999), Halpern and Korosi, (1997), Nesterova and Sabirianova (1998).
} 
indication of the problem is seen in the changes that have occurred in the composition of enrolments to secondary schools in the first half of the 1990s. As seen in Figure 3, while inflows into vocational education are everywhere declining, enrolments to general secondary are booming in all countries.

Unlike schooling, work experience under central planning was not rewarded more with the transition to a market economy. The premia placed on a year of experience declined in the Czech Republic (Chase, 1998; Munich et al., 1999), Eastern Germany (Bird et al., 1994; Krueger and Pischke, 1995), Hungary (Halpern and Korosi, 1997), Poland (Rutkowski, 1997) and Russia (Nesterova and Sabirianova, 1998). The exception is Slovenia, where Orazem and Vodopivec (1997) found that the returns to experience mildly rose from 1987 to 1991 , which is very early in the transition. However, in the majority of the transition economies there is strong evidence that the older workers are losing ground to the younger as the experience during the Communist period is not being valued in the labor market.

The profile of winners and losers is also affected by the characteristics of the region of residence. Wide and persistent labor market imbalances are reflected by statistically significant coefficients for regional dummies in virtually all regressions of wages or labor market outcomes. Several attempts have been made to interpret these regional effects in terms of a set of well-defined characteristics and economically meaningful taxonomies of regions (Huber and Scarpetta, 1993; Gora and Lehmann, 1995). These studies suggest that at early stages of transition, different types of regions were negatively affecting job finding probabilities and wages, while more recently regional labor market asymmetries overlap with the classic urban/rural divide.

Not only demand factors, but also labor supply is important in explaining the concentration of unemployment and, above all, non-employment in rural areas. 12 In any event, regional disparities are likely to remain given the low levels of interregional mobility and commuting flows registered in these countries in spite of widening unemployment and wage differentials (Boeri and Scarpetta, 1996; Erbenova, 1995).

\footnotetext{
${ }^{12}$ Estimates of reservation wage functions in rural and urban areas point to a profile of demand which is flatter in educational attainments in the urban areas (Boeri, 2000). The opportunity costs of working may be higher in cities for low-skilled types, not lastly because the cash transfers provided by the welfare state
} 
Overall, evidence from micro studies point to a rather well defined profile of winners and losers of transition. The winners have been so far young, educated, men, living in urban areas, with skills enabling them to exploit the opportunities offered in the emerging private sector. The losers are women and older workers, whose human capital has been relatively devalued, and have low incentives to acquire the new skills that are relevant to the emerging market economy. Given these characteristics, most losers are bound to remain losers. There is also evidence of factors making it more difficult to move from the group of losers to that of winners, such as marked regional imbalances in the allocation of employment opportunities, and the narrow base of many vocational education curricula, which reduce the fungibility of the workforce.

\section{Labor Market Adjustment, Earnings Inequality and Institutions}

The micro evidence reviewed above suggests that we have much to gain by adopting theoretical perspectives allowing for heterogeneity and labor supply related specificity in the workforce. Transition involves the development of new job matches, using workers with different skills and labor market attachments. Such differences were repressed under the previous regime, which forced everyone to work for the same number of hours and at almost the same wage rate. Thus transition, according to this perspective, should generate an explosion of earning differentials at all levels, between the public and private sectors, between and within firms as well as across regions. The explosion of earning inequalities may be, however, mitigated by institutions imposing wage floors. When these institutions are in place, we should expect transition to generate, ceteris paribus, more unemployment, as there are constraints to wage adjustment and low productivity workers are forced to leave the old sector. The wage floor can also inhibit the creation of low productivity jobs in the new sector. The empirical evidence above is consistent with this view, indicating that the less skilled workers are more likely to be unemployed than of the more skilled workers.

Such a perspective points to a key role for labor market institutions in mediating the transition. Some of these institutions, e.g., unemployment benefits, have been thoroughly investigated by the transition literature. Others, like unions, have received

are typically not adjusted to take into account of differences in the cost-of-living between large centers and 
much attention by work on the political economy of transition and surprisingly much less from empirical research. Before considering evidence in support of our theoretical perspective, it is useful to review what we have learned about the effects of these institutions in transition countries.

\subsection{Institutions and Labor Reallocation}

Four institutional features -- unions, tax based income policies, minimum wages and employment protection legislation - are typically considered important for employment and wage setting. Although there is little empirical research to date on the impact of these institutions, they appear to have had modest influence on the labor market in most transition economies. On the other hand, there has been a great amount of research on the impact of unemployment programs (both active and passive) on the duration of unemployment and the probability of finding a job. 13

The disorganization and segmentation of workers' organizations at the outset of transition was not only a by-product of a lack of credibility of the old unions, which had supported the Communist regime, it also resulted from the fact that the old unions were actually not rooted at the workplace. 14 Unions under the old system were "transmission belts" for authorities rather than voices for workers (Boeri, 2000). They were nourished by soft budget constraints and largely unprepared for tough wage negotiations and opposition to staff cuts. Some research on labor unions indicates that the "successor unions" were incapable of reform, pointing to the need to build new unions "from scratch" (Blanchflower and Freeman, 1997; Jones, 1995). Little is known about the effects of unionization on employment and wage setting in transition economies but there is evidence of strong declines in union membership, declining coverage of collective bargaining and an increasing segmentation of workers' organizations in a large number of unions competing among themselves (EC-ILO, 1995). For example, in 1996 only 30\% of the workers in the Czech Republic and Hungary were covered by collective wage agreements and in Lithuania, the share of union membership in the labor force fell to

rural areas, which in these countries can be of the order of $50 \%$.

${ }^{13}$ Passive unemployment programs refer to unemployment benefits while active programs refer to activities to assist workers in finding employment through training, assistance with job search, job subsidies, etc. 
$13 \%$ in 2000 from about $85 \%$ in 1989 (Vaughan-Whitehead, 1998). Whereas union representation is still high in Russia (in 1998 87\% of manufacturing enterprises had a union), workers organizations are not very effective as revealed by a high rate of contract violation, including wage arrears, and low strike activity (Earle and Sabirianova, 2001).

On the other hand, in the early part of transition the voice of workers was heard through worker' councils/collectives in some CEECs (e.g., Hungary, Poland and Slovenia, though not in former Czechoslovakia) and in Russia, though not in other FSU countries. Worker's councils had some control over the appointment of managers, wage setting and the allocation of profits, which generally went to workers (Hinds, 1990). This may explain why wage declines were greater in former Czechoslovakia than in Hungary or Poland during the early years of the transition. In Russia, the collectives may have influenced wage growth in 1990 and 1991, but, by 1992, they were not in a position to resist the erosion of the real value of their earnings.

Most governments feared that rapid wage growth would derail the transition and hence proceeded to implement tax based income policies (TIPs) to slow wage growth. Again, little empirical work has been carried out to date on the impact of these policies on wage setting but it is believed that these probably had modest influence on wage levels because a) they were set up and then removed intermittently, reducing the credibility of tax penalties and allowing for intervals of "wage catch-up"; b) they were usually designed to control the average wage of the firm, hence substitution was allowed within the firm; and c) they were usually only enforced in the large public enterprises, and not in the new private sector. By 1995 many of the CEECs (the Czech Republic, Hungary, Poland and Slovakia) had abandoned TIPs; Russia abolished them in 1996. However, TIPs were still in place in Bulgaria, Romania and in the Ukraine in $1996 .{ }^{\text {․․ }}$

Minimum wages, legislated in almost all of these countries at the start of transition, were initially set in the CEECs at levels comparable to those in the West (about $45-50 \%$ of the average wage), whereas in Russia and Ukraine the ratios were 27\% and $32 \%$ respectively (Figure 4). In all of the transition economies this ratio fell over

\footnotetext{
${ }^{14}$ To give an example, IG Metall, the powerful Western German metalworkers' union, had originally planned to merge with its Eastern counterpart, but gave up this idea when it found that the Eastern German union was in fact an organization subordinate to the Communist Party, and not embedded at the workplace.

${ }^{15}$ See Vaughn-Whitehead, 1998 for an assessment of wage policy reforms in the transition economies.
} 
time, as minimum wages were consciously unaltered for several years in periods of high inflation as a way to control wage growth. For instance, in the Czech Republic the minimum wage was kept at 2,200 crowns from 1992 to the end of 1995 and declined by about 50 percent in real terms. By 1996 minimum wages had fallen to about 30\% of the average wage in all CEECs and 6\% in Russia and in the Ukraine.

These minimum wages were not binding throughout most of the transition. In Hungary, for example, the percentage of the employees in the competitive sphere who were paid the minimum wage or less fell from $10 \%$ in 1991 to $2 \%$ in 1995 (VaughanWhitehead, 1998). One of the reasons why minimum wages were de facto not used as a policy tool is that they were to a large extent non-enforceable, due to the weakness of bargaining institutions and a lack of an efficient network of labor inspectors in these countries. However, minimum wages played some role indirectly: in all the transition economies they serve as the basis for calculating most social benefits (e.g., welfare, unemployment, and health benefits). They may have also influenced wage growth in the public administration in Russia.

Under the previous regime, employers in most countries could not easily layoff their workers. At the outset of transition, Labor Codes were revised to allow for employment protection regulations, requiring severance pay and notice periods in case of dismissals. These norms do not appear particularly restrictive by Western European standards. They consist mainly of transfers between employers and their employees, such as severance pay or an extension of the duration of the job, due to the compulsory notice, rather than taxes to be paid to a third party (such as procedural and legal obstacles) that impose a deadweight cost (Boeri, 2000). The relatively high flexibility of labor markets in the CEECs and the FSU is generally acknowledged by employers. According to the international Institute for Management Development (IMD) survey of about 4,000 business executives worldwide (IMD, 1998), CEECs and Russia have scores ranging from a low 5.2 in Poland to a high 7.2 in Hungary compared with 6.9 in the US and 2.3 in Italy. Furthermore there seems to be a weak enforcement of employment

\footnotetext{
${ }^{16}$ One cannot rule out the possibility that minimum wages could have affected collective wage bargaining above the minimum. However, strongly declining Kaitz ratios (ratios of the minimum wage to the average wage) suggest that this influence should have been mild, at most.
} 
protection regulations, due to limited court capacity. To give an example, in Russia almost $50 \%$ of the labor disputes related to unfair dismissals is not concluded within the deadline stipulated by law (Denisova, Friebel and Sadovnikova, 1998). Significantly, while in countries with strict employment protection regulations, the number of lawsuits filed by employees and the percentage of court rulings favorable to workers are typically increasing in years of employment decline, in Russia both figures are flat over the 1990s.

The jury is still out as to whether the expansion of the scope of active labor market policies (such wage subsidies, direct job creation and schemes for school-leavers) had an impact on reducing unemployment duration. In the Czech Republic, where in one year a large number of job seekers were in such programs, the findings are mixed. Boeri (1997) found that when interacted with cuts to benefit duration, active policies have had some impact on job finding probabilities and were relatively cost-effective. According to his estimates in 1993 in the Czech lands the monthly cost of any additional outflow from unemployment to jobs induced by active policy was in the range of 4 to $7 \%$ of the average monthly wage, compared with an average unemployment benefit offering roughly $30 \%$ of the average wage. On the other hand, Munich et al. (1999), using more years of data, did not find a positive effect of expenditures on active labor market policies on unemployment outflows. In other countries active policies proved rather poorly targeted (Micklewright and Nagy, 1996), or associated with "policy circles" where participants in active schemes requalify for benefit payment (Kluve, Lehmann and Schmidt, 1999). There is some evidence that active policies are among certain groups: Terrell and Sorm (1999) found that expenditures for active labor market in the Czech Republic were targeted to the "hard to employ" population and these individuals benefited from the program with higher-than-otherwise outflows from unemployment.

In the CEECs unemployment benefits were initially set at relatively high levels and provided in some cases for unlimited duration. They were subsequently tightened as the number of beneficiaries was skyrocketing and fiscal consolidation was required. To give a few examples, the maximum duration of unemployment benefits was halved in former Czechoslovakia and in Hungary, and a maximum duration of one year was set in Poland, which had initially adopted an open-ended system. Gross statutory replacement rates were also decreased in Bulgaria, in the former Czechoslovakia and in Poland. The 
introduction of benefit ceilings ranging between 140 and $180 \%$ of the minimum wage also contributed to reducing benefit levels. Needless to say, in OECD countries cuts in the generosity of benefits are rarely made and when so, are much less radical and diluted over a longer time period.

Several studies have tried to exploit these "natural experiments" to draw conclusions as to the incentive effects associated with the provision of unemployment insurance. Some of them have used regional level data on unemployment outflows to estimate the impact of changes in the benefit regime on aggregate matching functions. ${ }^{17}$ Others have used individual data from unemployment registers or surveys designed to elicit retrospective information. ${ }^{18}$ None of these studies point to a significant increase in exits from unemployment to employment after the tightening of unemployment insurance systems. The elasticity's of unemployment duration with respect to changes in benefits ranges from 0.1 in Slovakia to 0.3 in the Czech Republic to 0.7 in East Germany and Hungary, which are moderate compared with other studies in the United States, Canada and Europe. ${ }^{1.9}$ Hence, unemployment benefits per se did not create strong work disincentive effects.

\subsection{Non-employment Benefits as Wage Floors}

Whereas the impact of non-employment benefits schemes on the labor market flows has been extensively examined, their role in influencing wages has been overlooked in the literature. However weak unions and the lack of enforcement of minimum wages ended up assigning to unemployment benefits, and the whole battery of subsidies to non-employed individuals in working age, a non-standard function: they put a floor to wage setting. Diverging wage and hence employment trajectories across the CEECs and the FSU can be partly attributed just to differences in the design of nonemployment programs. 20

\footnotetext{
${ }^{17}$ See e.g., Boeri and Burda, 1996; Munich, Svejnar and Terrell, 1999.

${ }^{18}$ See e.g., Bellmann et al., 1995 for former East Germany; Ham, Svejnar and Terrell, 1998, 1999 for the Czech Republic and Slovakia; Micklewright and Nagy, 1994, 1997 for Hungary; and Puhani, 2000 for Poland

${ }^{19}$ See Svejnar (1999) for a review of the empirical literature measuring the impact of unemployment benefit schemes on unemployment duration.

${ }^{20}$ Garibaldi and Brixiova (1998) make a similar argument. They develop a dynamic matching model, which predicts that: a) unemployment benefits increase steady-state unemployment and speed up closure of state enterprises by reducing the fall in real wages; b) higher minimum wages speed up closure of the old sector but do not affect steady state unemployment benefits.
} 
Table 4 displays some summary statistics on non-employment benefits and earnings (levels and distributions) in the CEECs and FSU countries. In particular, the first two columns show the relative importance played by non-employment benefits (defined as unemployment benefits, welfare assistance, disability benefits and sickness benefits) in terms of GDP share and as a fraction of social policy expenditure. Clearly, the FSU countries have budgeted far less for non-employment subsidies and the generosity of their benefits is relatively low compared to the CEECs (which are lower than the EU countries). Columns 3 and 4 provide summary measures of the way in which non-employment benefits interfere with the wage distribution. They contrast the share of income replaced for those in the upper portion of the earnings distribution (earning two times the average wage) with those whose wages are at the lower end of the distribution (two-thirds the average wage), both adjusted for inflation. The ratios suggest that in Russia non-employment benefits do not redistribute in favor of low wage earners as much as in the CEECs, where the replacement rate for those earning two-thirds of the average wage is two to three times larger than for those earning twice the average wage. 21

Acknowledging problems with cross-country comparisons of earning inequality measures, Table 4 points to a much stronger increase in inequality in the FSUs than in the CEECs. Significantly, the difference in the dynamics is due largely to the bottom of the distribution falling in the FSU whereas it was keeping its share in the Visegrad countries. Gini decomposition analysis of the Czech and Slovak Republics (Garner and Terrell, 1998) and of Russia (Commander and Lee, 1998) indicate that the relative difference in the rise in the Gini in these two regions, as well as the relative change in the share of income of the bottom decile, is driven by changes in both the generosity and the degree of targeting of non-employment benefits. ${ }^{22}$ Within Central and Eastern Europe, the largest increases in Gini coefficients ratio was recorded in Romania, which devotes fewer resources to non-employment benefits relative to both, GDP and the overall social policy envelope than the other CEECs.

\footnotetext{
${ }^{21}$ Within the CEECs there is of course variation as well. For eg., the Slovakian unemployment scheme was considered to have redistributed benefits the most to the lower end of the wage distribution (see Vodopivec et al., 2001).

${ }^{22}$ Calculations from micro data (HEIDI, Household Expenditure and Income Data for Transitional Economies) reported in Vodopivec et al. (2001) are consistent with this role played by unemployment benefits in containing inequalities in the CEECs.
} 
There is some econometric evidence on the impact of non-employment benefits on wage setting. Estimates of Mincerian earning functions controlling for selectivity bias (that is, including a term reflecting the probability that the individual is employed) confirm the impression given by Table 4 concerning the role played by non-employment benefits as de facto minimum wages (Boeri, 2000). Moreover, microeconomic evidence on labor supply behavior in countries with a flat-rate unemployment benefit, like Poland, also suggest that unemployment benefit receipt increases reservation wages of individuals (Boeri and Flinn, 1999).

All in all, the countries with lower levels of spending in non-employment benefits and replacement rates that are only mildly decreasing with previous earnings experienced the largest increases in the inequality of earnings. Although it is difficult to draw causal inferences from cross-country comparisons involving a few observations, the evidence does not contradict the view that the design of non-employment benefits played an important role in shaping the earning distribution of the CEECs.

Cross-country differences in the scope of redistribution in favor of non-employed individuals in working age may also contribute to explaining the differences in labor market adjustment trajectories documented in Section 2. In the CEECs, where nonemployment benefits were higher and in favor of the low income earner, aggregate wage declines were much less pronounced and earning inequalities increased to a lower extent than in Russia and the Ukraine. As a result, in the FSU the bulk of adjustment involved wages whereas in the CEECs it was mainly employment that bore the weight of adjustment.

\section{Conclusions}

We began this paper by raising a number of issues regarding the patterns of labor reallocation in transition economies. We can, at this stage, speculate on possible answers, not yet empirically falsified. Further research with more observations and better data than those currently available would be required to test these hypotheses properly.

We showed that the paths of labor market adjustment differed in many of these countries but there appears to be a larger difference between the CEECs and the FSU

\footnotetext{
${ }^{23}$ Huitfeldt (2001) also found that active labor market policies exerted upward pressure on the lower end of
} 
countries in the responsiveness of employment to output changes, the extent of real wage decline, the amount of reallocation of labor from the old to the new sector, the degree of wage dispersion, as well as the timing of the rise of unemployment and its duration. We also showed that in all of these countries there was a clear pattern of winners and losers.

Why was labor market adjustment so different in the CEECs and the FSU? In part this can be explained by the two different models of social policy that were adopted in these two groups of countries. The model followed by the CEECs (notably by the Visegrad four) assigned a much greater role to non-employment benefits than the model followed by the FSU countries. The higher level of non-employment benefits implied floors to wage distributions and prevented further decline of wages. However, we do not rule out the role that other institutions may have also played in the wage-employment trade-off and where we still do not have sufficient information. All this generated more quantity than price adjustment in the CEECs vis-a-vis the FSUs.

Why was the CEEC model more conducive to structural change than the FSU model? The wage floor imposed by non-employment benefits in the CEECs meant that old and inefficient firms were forced to shed their least productive labor rather than being allowed to adjust wages downwards or even accumulate wage arrears, as occurred in Russia. Non-employment benefits also imposed a wage floor in the private sector, which made jobs in the new gap-filling, retail service sector more attractive but, at the same time, more difficult for the least skilled workers to obtain, and hence created more unemployment among them. In addition, non-employment benefits may have also operated as a subsidy to job creation in the new sector, as the self-employed and the new small business sector were allowed to combine benefits and earnings from work obtaining explicit or hidden seed capital for the start-up of new entrepreneurial activities. In the FSU unemployment benefits were too low to be used as start-up subisidies and there were marked entry barriers associated with mafia and smuggling. Overall, more quantity, as opposed to price, adjustment in the CEECs implied faster structural change, which in turn allowed for stronger growth later on than in the FSU (although there are signs in recent years that the Russian economy may be "turning the corner").

the wage distribution in the Czech and Slovak Republics. 
Why were these two different social policy models adopted by countries starting from similar initial conditions and having the opportunity to introduce from scratch nonemployment benefits? Further work, taking a political economy perspective, will have to address these issues. At a first sight, it is difficult to attribute the cross-country variation in the size and composition of social spending to differences to in the degree of inequality aversion, as historical and cultural roots were similar as well as past records of income inequality. Differences in the degree of economic development or access to international capital markets, making it more difficult for the FSU to sustain large social policy outlays cannot entirely explain the differences in the policy mix. The budget of the Russian Federal Employment Service, in charge of paying unemployment benefits, was for many years in surplus. Rather than accumulating surpluses, such moneys could have been used to improve the coverage (if not the level) of benefits. The most convincing explanation for these differences in policy models relates to the more or less strict conditionality and appeal of the EU social policy model vis-a-vis the transition countries.

Which one of the two models is preferable? There are relevant trade-offs involved by the choice between the two social policy models. More redistribution in favor of nonemployed individuals generated more unemployment in the CEECs throughout the transition. Most of this unemployment is long term. However, the social policy model adopted in the CEECs allowed for faster structural change to occur, contributing to growth later on in the transition and less inequality (Milanovic, 1998; Garner and Terrell, 1998). Thus the overall balance would seem to be in favor of the CEEC model. This does not mean that in the transition to a market economy it is always advisable to have institutions containing the growth of wage inequality. It depends also on the type of institutions involved. One thing is to have non-employment benefits putting a floor to wage setting. Another thing is to import centralized wage bargaining institutions compressing the whole earning structure, as happened in the case of Eastern Germany. 


\section{REFERENCES}

Abraham, Katherine and Milan Vodopivec (1993) "Slovenia; a Study of Labor Market Transition," mimeo, Washington DC: The World Bank.

Aghion, Philippe and Olivier Blanchard (1994) "On the Speed of Transition in Central Europe," NBER Macroeconomics Annual, pp. 283-320.

Atkinson, Anthony B. and John Micklewright (1992) EconomicTransformation in Eastern Europe and the Distribution of Income. Cambridge: Cambridge University Press.

Basu, Swati, Saul Estrin and Jan Svejnar (1999) "Employment and Wage Behavior of Enterprises under Communism and in Transition: Evidence from Central Europe and Russia," Davidson Institute Working Paper No. 114, Ann Arbor: William Davidson Institute.

Bellmann, Lutz, Saul Estrin, Hartmut Lehmann and Jonathan Wadsworth (1995) "The Eastern German Labor Market in Transition: Gross Flow Estimates from Panel Data," Journal of Comparative Economics. 20:2, pp.139-170.

Blanchflower, David G. (2000) "Unemployment, Well-being and Wage Curves in Eastern Europe," unpublished manuscript, Department of Economics, Dartmouth College, February.

Blanchflower, David G. and Richard B. Freeman (1997) "The Attitudinal Legacy of Communist Labor Relations," Industrial and Labor Relations Review, 50:3, pp. 438-459.

Bird, Edward, Johannes Schwarze, and Gert Wagner (1994), "Wage Effects of the Move toward Free Markets in East Germany," Industrial and Labor Relations Review 47:3, pp. 390-400.

Boeri, Tito (2000) Structural Change, Welfare Systems and Labor Reallocation, Oxford: Oxford University Press.

(1998) "Labor Market Flows in the Midst of Structural Change," in Simon Commander (ed.) Enterprise Restructuring and Unemployment in Models of Transition, EDI, Development Studies, Washington, pp. 143-167.

(1997) "Learning from Transition Economies: Assessing Labor Market Policies across Central and Eastern Europe," Journal of Comparative Economics, 25, pp. 366-384.

Boeri, Tito and Michael Burda (1996) "Active Labor Market Policies, Job Matching and the Czech Miracle," European Economic Review, 40, pp. 805-817. 
Boeri, Tito and Edwards Scott (1998) "Long-term Unemployment and Short-term Unemployment Benefits," Empirical Economics, 23, pp. 31-54.

Boeri, Tito and Christopher Flinn (1999) "Returns to Mobility in the Transition to a Market Economy," Journal of Comparative Economics, 27:1, pp. 4-32.

Boeri, Tito and Stefano Scarpetta (1996) "Regional Mismatch and the Transition to a Market Economy," Labour Economics, 14:3, pp. 233-254.

Brainerd, Elizabeth (1998) "Winners and Losers in Russia's Economic Transition," American Economic Review, 88:5, pp. 1094-1116.

Castanheira, Micael and Gerard Roland (2000) "The Optimal Speed of Transition: A General Equilibrium Analysis, ” International Economic Review, 41:1, pp. 21939.

Chase, Robert S (1998) "Markets for Communist Human Capital: Returns to Education and Experience in Post-Communist Czech Republic and Slovakia," Industrial and Labor Relations Review, 51:3, pp. 401-423.

Commander, Simon and Une Lee (1998) "How does Public Policy affect the Income Distribution? Evidence from Russia, 1992-1996," unpublished paper, EBRD and the World Bank, December.

Denisova, Irena, Guido Friebel and Elena Sadovnikova (1998) "The Russian labour Market - urgent Reform Needs," in Russian Economic Trends, (2), pp. 9-14.

Earle, John S. and Zuzana Sakova (2000) "Business Start-ups or Disguised Unemployment? Evidence on the Character of self-employment from Transition Economies," Labour Economics, 7, pp. 575 - 601.

Earle, John S. and Klara Sabirianova (2001) "Coping with Crisis: Russian Labor Markets in Transition”, World Bank, fortcoming.

EC-ILO (European Commission and International Labour Office) (1995) "Reforming Wage Policy in Central and Eastern Europe," Geneva: EC-ILO.

Erbenova, Michaila (1995) "Regional Unemployment Differentials and Labor Mobility: A case-study of the Czech Republic," in OECD, The Regional Dimension of Unemployment in Transition Countries, Paris, Organization for Economic Cooperation and Development.

European Bank for Reconstruction and Development (EBRD) (1995) Transition Report 1995.

European Bank for Reconstruction and Development (EBRD) (1999) Transition Report 1999. 
European Bank for Reconstruction and Development (EBRD) (2001) Transition Report 2000.

European Bank for Reconstruction and Development (EBRD) (2001) Transition Report Update 2001.

Flanagan, Robert J. (1993) “Were Communists Good Human Capitalists? The Case of the Czech Republic," mimeo. Stanford University.

Foley, Mark C. (1997) "Labor Market Dynamics in Russia," Yale University, Economic Growth Center Discussion Paper No. 780.

Garibaldi, Pietro and Zuzana Brixiova (1998) "Labor Market Institutions and Unemployment Dynamics in Transition Economies," IMF Staff Papers, 45:2, pp. 269-308.

Garner, Thesia and Katherine Terrell (1998) "A Gini Decompositon Analysis of Inequality in the Czech and Slovak Republics During the Transition," The Economics of Transition, 1:6, pp. 23-46.

Gora, Marek and Hartmut Lehmann (1995) "How Divergent is Regional Labor Market Adjustment in Poland" in Stefano Scarpetta and Andreas. Wörgötter (eds.) The Regional Dimension of Unemployment in Transition Countries: A Challenge for labor Market and Social Policies, OECD, Paris.

Halpern, Lazlo, and Gabor Korosi (1997) "Labor Market Characteristics and Profitability: Econometric Analysis of Hungarian Firms, 1986-1995," The William Davidson Institute Working Paper No. 41.

Ham, John, Jan Svejnar and Katherine Terrell (1998) "Unemployment and the Social Safety Net During the Transition to a Market Economy: Evidence from Czech and Slovak Men”, American Economic Review, 88:5, pp. 1117-42.

Hinds, Manuel (1990) "Issues in the Introduction of Market Forces in Eastern European Socialist Economies," Internal Discussion Paper 57, World Bank.

Huber, Peter and Stefano Scarpetta (1995) ___ in Stefano Scarpetta Andreas Wörgötter (eds.), Regional Dimension of Unemployment in Transition Countries--A Challenge for Labour Market and Social Policies, Paris: OECD.

Huitfeldt, Henrik (2001) "Unemployment, Labour Market Programmes and Wage Determination: Evidence from the Czech and Slovak Republics," Department of Economics, Uppsala University, Sweden.

IMD (International Institute for Management Development) (1998). The World Competitiveness Yearbook. Lausanne, Switzerland. 
Jones, Derek C., and Takao Kato (1997) "The Nature and the Determinants of Labor Market Transitions in Former Communist Economies: Evidence from Bulgaria," Industrial Relations, 36:2, pp. 229-254.

Jones, Derek C. (1995) "Successor Unions in Transitional Economies: Evidence from St. Petersburg," Industrial \& Labor Relations Review, 49:1, pp. 39-57.

Jurajda, Stepan and Katherine Terrell (2001) "The Optimal Speed of Transition: Evidence from the Czech Republic" William Davidson Working Paper No. 157, University of Michigan.

King, Arthur E. and Vera A. Adamchek (1999) "The Impact of Private Sector Development on Unemployment, Labor Force Reallocation and Labor Market Flows in Poland," unpublished paper presented at the annual meetings of the ACES, New York, Jan. 2-4.

Kluve, Jochen, Hartmut Lehmann and Christoph M. Schmidt (1999) "Active Labor Market Policies in Poland: Human Capital Enhancement, Stigmatization or Benefit Churning?" Journal of Comparative Economics, 27:1, pp.61-89.

Krueger, Alan B., and J. S. Pischke (1995) "A Comparative Analysis of East and West German Labor Markets: Before and After Unification." in Freeman, R.B., and Katz, F., (eds.) Differences and Changes in Wage Structures, Chicago: The University of Chicago Press.

Lacko, Maria (1999) "Hidden Economy: an Unknown Quantity? Comparative Analysis of Hidden Economies in Transition Countries in 1989-95" Johannes Kepler Universitat Linz Working Paper No. 9905.

Lehmann, Hartmut and Jonathan Wadsworth (1999) "Tenures that Shook the World: Worker Turnover in the Russian Federation and Poland," William Davidson Institute Working Paper No. 160

Micklewright, John and Giulia Nagy (1994) "Flows to and from Insured Unemployment in Hungary" Florence: European University Institute Working Paper No. 9441.

(1996) "Labor Market Policy and the Unemployed in Hungary", European Economic Review, 40:3-5, pp.819-828.

Milanovic, Branko (1998) Income, Inequality, and Poverty during the Transition: from Planned to Market Economy, Washington, D.C.: World Bank.

Munich, Daniel, Jan Svejnar and Katherine Terrell (1999) "Worker-Firm Matching and Unemployment in the Transition to a Market Economy: (Why) Are the Czechs more Successful than Others?" CERGE-EI Working Paper No.141. 
. (1998) "The Returns to Human Capital Under Communism Wage Grid and During the Transition to a MARket Economy "William Davidson Working Paper No. 272

Nesterova, Daria and Klara Sabirianova (1998) "Investment in Human Capital During the Economic Transformation in Russia," Economic Education and Research Consortium, Working Paper No. 99/04, Moscow.

OECD (1994) Unemployment in the Transition Countries: Transient or Persistent? Organization for Economic Co-operation and Development, Paris.

OECD (1997) Employment Outlook. Organization for Economic Co-operation and Development, Paris.

OECD (1999) Economic Survey of the Slovak Republic. Organization for Economic Cooperation and Development, Paris.

Orazem, Peter F., and Milan, Vodopivec (1997) "Unemployment in Eastern Europe, Value of Human Capital in Transition to Market: Evidence from Slovenia." in Papers and Proceedings of the Eleventh Annual Congress of the European Economic Association, European Economic Review, pp.893-903.

Psacharopoulos, George (1994) "Returns to Education: A Global Update," World Development 22:9, pp. 1325-1343.

Puhani, Patrick A. (2000) "Unemployment benefit Entitlement and Training Effects in Poland During Transition," Journal of Population Economics, 1, pp. 35-44

Rutkowski, Jan (1997) "Low Wage Employment in Transitional Economies of Central and Eastern Europe." MOST, 7, pp.105-130.

Sorm, Vit and Katherine Terrell (2000) "Sectoral Restructuring and Labor Mobility: A Comparative Look at the Czech Republic," Journal of Comparative Economics, 28:2, pp. 431-455.

Svejnar, Jan (1999) "Labor Markets in the Transitional Central and Easter European Economies," in Orley Ashenfelter and D. Card (eds.) Handbook for Labor Economics, vol. 3-4, North Holland: Elsevier Publishers.

Terrell, Katherine and Vit Sorm (1999) "Labor Market Policies and Unemployment in the Czech Republic,” Journal of Comparative Economics, 27:1, pp. 33-60.

Terrell, Katherine (1999) "Worker Mobility and Transition to a Market Economy: Winners and Losers," Chapter 7 in Nancy Birdsall and Carol Graham (eds.) New Markets, New Opportunities? Economic and Social Mobility in a Changing World, Brookings Institution.

UNICEF (1999) CEE/CIS/ Baltics Regional Monitoring Report. 
Vaughan-Whitehead, Daniel (1998) "Wage Policy Reforms in Central and Eastern Europe: A First Assessment," Ch. 2 in D. Vaughan-Whitehead (ed.) Paying the Price: The Wage Crisis in Central and Eastern Europe, Great Britain, Macmillan Press, pp. 13-81.

Vodopivec, Milan (2000) "Worker Reallocation During Estonia's Transition to Market" unpublished paper, the World Bank, September.

Vodopivec, Milan, Adreas Wörgötter, Dhushyanth Raju (2001) "Unemployment Benefits in Transition Economies: Lessons Learned and Policy Options," unpublished paper, the World Bank, February.

World Bank (1998) Privatization and Restructuring Database. World Bank, Washington.

World Bank (2001) World Development Report 2000/2001. World Bank, Washington. 
Table 1: Structural Change and Unemployment Dynamics

\begin{tabular}{|c|c|c|c|c|c|c|c|c|}
\hline \multirow[b]{3}{*}{ Country } & \multicolumn{3}{|c|}{ Across Economic Activity } & \multirow{2}{*}{$\begin{array}{c}\text { Ownership Changes } \\
\text { Private Sector } \\
\text { Employment Share } \\
(\%) \text { in } 1997\end{array}$} & \multirow{2}{*}{$\begin{array}{c}\text { Small Firms } \\
\text { Employment Share in } \\
\text { Firms Less than } 100 \\
\text { employees } \\
\text { in } 1996\end{array}$} & \multirow{2}{*}{$\begin{array}{c}\text { Self-employment } \\
\text { Non-agricultural self- } \\
\text { employment } \\
\text { (\% of Employed }) \\
\text { in } 1998\end{array}$} & \multicolumn{2}{|c|}{ Unemployment Dynamics } \\
\hline & 1989-98 C & $\begin{array}{l}\text { nge in the } \\
\text { re (in perc }\end{array}$ & $\begin{array}{l}\text { ployment } \\
\text { Services }\end{array}$ & & & & $\begin{array}{c}\text { First Peak in } \\
\text { unemployment rate } \\
\text { (years from the start } \\
\text { of transition) }\end{array}$ & $\begin{array}{l}\text { Mean share in } \\
\text { long term } \\
\text { unemployment } \\
(1994-1998)\end{array}$ \\
\hline & (1) & (2) & (3) & (4) & (5) & (6) & (7) & (8) \\
\hline \begin{tabular}{|l|} 
CEECs \\
\\
of which
\end{tabular} & -0.04 & -10.0 & 10.1 & 64.7 & 41.7 & & & 43.9 \\
\hline Czech Republic & -6.2 & -5.9 & 12.1 & 59.7 & 46.9 & 13.2 & $9.4(9)$ & 26.8 \\
\hline Hungary & -9.1 & -6.0 & 15.1 & 80.0 & 40.7 & 13.1 & $13.9(2)$ & 47.6 \\
\hline Poland & 0.6 & -7.9 & 7.4 & 64.0 & 50.3 & 16.0 & $16.4(4)$ & 39.0 \\
\hline Romania & 12.1 & -14.2 & 2.1 & 55.0 & $\ldots$ & $\ldots$ & $9.2(3)$ & 46.6 \\
\hline Slovenia & 3.0 & -12.5 & 9.5 & $\ldots$ & 31.4 & 9.2 & $15.4(3)$ & 54.1 \\
\hline Slovak Republic & -6.0 & -10.6 & 16.6 & 64.6 & 44.8 & $\ldots$ & $14.6(4)$ & 49.5 \\
\hline FSUs & 6.9 & -11.6 & 4.5 & & & & & \\
\hline Russian Fed. & 0.04 & -10.5 & 11.1 & 65.0 & 13.0 & 6.3 & $13.3(7)$ & 32.0 \\
\hline Ukraine & 2.3 & -12.9 & 10.6 & 52.0 & $\ldots$ & 1.4 & $4.3(8)$ & $\ldots$ \\
\hline Belarus & -2.1 & -7.3 & 9.1 & $\ldots$ & $\ldots$ & $\ldots$ & $3.9(5)$ & $\ldots$ \\
\hline Kazakhstan & 3.1 & -12.9 & 10.8 & $\ldots$ & $\ldots$ & $\ldots$ & $14(7)$ & $\ldots$ \\
\hline
\end{tabular}

Notes:

Col. 1, 2 and 3: data refer to the period 1990-1997; "Agriculture": Agriculture, hunting, forestry and fishing; "Industry": Manufacturing; Mining and quarrying; Electricity, gas and water; Construction "Services": Finance, insurance, real estate and business service; Community, social and personal services; Wholesale; Transport.

Col. 5: Slovakia (1997)

Col. 7: Poland (1989), other CEECs (1990), FSU (1991)

Col. 8: "Long Term unemployment" is defined as "unemployed for 12 or more months"

Sources:

Col. 1, 2 and 3: OECD Short Term Economic Indicators various issues for CEECs; EBRD Transition Report 1999 for FSU

Col. 4: Privatization and Restructuring Database, World Bank 1998 and EDIMP's Window into Economic Policy, World Bank.

Col. 5: EBRD Transition Report 2000 and OECD Economic Survey of the Slovak Republic (February, 1999).

Col. 6: EBRD Transition Report 1999; for Slovenia: Slovenian Statistiscal Yearbook 1998

Col. 7 and 8: Boeri (2000) 
Table 2: Transition Probabilities for Six Transition Economies and the U.S.

\begin{tabular}{l|ccccccc}
\hline Country & Reference Year & Peu & Peo & Pue & Puo & Poe & Pou \\
\hline CEECs: & & & & & & & \\
Bulgaria (1) & $1994-1995$ & 0.059 & 0.092 & 0.323 & 0.244 & 0.092 & 0.044 \\
Czech Republic (2) & $1994-1995$ & 0.013 & 0.028 & 0.496 & 0.129 & 0.042 & 0.012 \\
Czech Republic (2) & $1996-1997$ & 0.008 & 0.025 & 0.457 & 0.101 & 0.040 & 0.008 \\
Czech Republic (2) & $1998-1999$ & 0.018 & 0.025 & 0.335 & 0.090 & 0.036 & 0.017 \\
E. Germany (3) & $1990-1991$ & 0.093 & 0.071 & 0.350 & 0.277 & 0.160 & 0.041 \\
Poland(4) & $1992-1993$ & 0.040 & 0.076 & 0.361 & 0.158 & 0.095 & 0.045 \\
Poland(4) & $1993-1994$ & 0.040 & 0.063 & 0.354 & 0.159 & 0.074 & 0.043 \\
Slovakia (1) & $1994-1995$ & 0.023 & 0.045 & 0.237 & 0.078 & 0.018 & 0.017 \\
FSU: & & & & & & & \\
Estonia(5) & $1992-1992$ & 0.048 & 0.097 & 0.465 & 0.093 & 0.143 & 0.036 \\
Estonia (5) & $1997-1997$ & 0.047 & 0.040 & 0.372 & 0.064 & 0.074 & 0.038 \\
Russia(6) & $1992-1993$ & 0.032 & 0.058 & 0.520 & 0.157 & 0.087 & 0.014 \\
Russia(6) & $1995-1996$ & 0.056 & 0.062 & 0.395 & 0.145 & 0.076 & 0.034 \\
\hline \hline United States (1) & $1992-1993$ & 0.028 & 0.053 & 0.659 & 0.288 & 0.043 & 0.161 \\
\hline
\end{tabular}

Sources:
(1) Boeri, 1998.
(4) Gora and Lehmann, 1995.
(2) Sorm and Terrell, 2000
(5) Vodopivec, 2000.
(3) Bellmann et al ., 1995.
(6) Foley, 1997. 
Table 3: Returns to a Year of Education

\begin{tabular}{|c|c|c|c|c|c|}
\hline \multirow[b]{2}{*}{ Country } & \multirow{2}{*}{$\begin{array}{c}\text { Reference } \\
\text { Years }\end{array}$} & \multicolumn{2}{|c|}{ Communism } & \multicolumn{2}{|c|}{ Transition } \\
\hline & & Men & Women & Men & Women \\
\hline CEECs & & & & & \\
\hline Czech Republic (1) & 1984,1993 & 0.024 & 0.042 & 0.052 & 0.058 \\
\hline Czech Republic (2) & 1989,1996 & 0.027 & 0.038 & 0.058 & 0.070 \\
\hline East Germany (3) & 1989,1991 & \multicolumn{2}{|c|}{0.044} & \multicolumn{2}{|c|}{0.041} \\
\hline East Germany (4) & 1988,1991 & \multicolumn{2}{|c|}{0.077} & \multicolumn{2}{|c|}{0.062} \\
\hline & & 0.071 & 0.085 & & \\
\hline Poland (5) & 1987,1992 & \multicolumn{2}{|c|}{0.05} & \multicolumn{2}{|c|}{0.07} \\
\hline Slovakia (1) & 1984,1993 & 0.028 & 0.044 & 0.049 & 0.054 \\
\hline \multicolumn{6}{|l|}{$F S U$} \\
\hline Russia (6) & 1991,1994 & 0.031 & 0.054 & 0.067 & 0.096 \\
\hline \multirow[t]{2}{*}{ Russia (8) } & 1998 & & & 0.076 & 0.102 \\
\hline & & & & \multicolumn{2}{|c|}{0.093} \\
\hline United States (4) & 1989 & - & - & 0.085 & 0.103 \\
\hline
\end{tabular}

Notes:

Figures are reported coefficients from human capital (Mincer, 1976) earnings functions. The exception is the study by Chase (1998) which corrects the womens' earnings functions for selectivity bias.

Sources:
(1) Chase, 1998.
(5) Rutkowski, 1997.
(2) Munich et al., 1998.
(6) Brainerd, 1998.
(3) Bird et al., 1994.
(7) Psacharopoulos, 1994
(4) Krueger \& Pischke, 1995.
(8) Nesterova and Sabrianova, 1998 
Table 4: Earnings Inequality and Non-Employment Benefits in Selected Transition Economies

\begin{tabular}{|c|c|c|c|c|c|c|c|c|}
\hline \multirow{4}{*}{ Region } & \multicolumn{4}{|c|}{ Non-Employment Benefit System } & \multirow{2}{*}{\multicolumn{2}{|c|}{$\frac{\text { Earnings Inequality }}{\text { Gini }}$}} & \multirow{2}{*}{\multicolumn{2}{|c|}{$\begin{array}{c}\text { Income Inequality } \\
\text { Share of Income (1996) }\end{array}$}} \\
\hline & \multicolumn{2}{|c|}{ 1991-95 Expenditure } & \multicolumn{2}{|c|}{ Replacement Rate at: } & & & & \\
\hline & $\% \mathrm{GDP}$ & $\%$ soc exp & $\begin{array}{c}2 \text { times the } \\
\text { average wage }\end{array}$ & $\begin{array}{c}2 / 3 \text { of the } \\
\text { average wage }\end{array}$ & $1987-89$ & 1997 & $\mathrm{P} 10$ & P90 \\
\hline & (1) & (2) & (3) & (4) & (5) & $(6)$ & (7) & (8) \\
\hline \multicolumn{9}{|l|}{$\overline{C E E}$} \\
\hline Bulgaria & 1.6 & 17.2 & 18 & 47 & 21.0 & 29.1 & 3.4 & 22.5 \\
\hline Czech Republic & 3.6 & 32.7 & 21 & 52 & 20.0 & 25.9 & 4.3 & 22.4 \\
\hline Hungary & 2.4 & 32.3 & 18 & 50 & 27.0 & 34.8 & 3.9 & 24.8 \\
\hline Poland & 5.0 & 31.8 & 14 & 46 & 21.0 & 30.0 & 3.0 & 26.3 \\
\hline Romania & 1.9 & 27.5 & 16 & 40 & 19.0 & 42.2 & 3.7 & 22.7 \\
\hline \multicolumn{9}{|l|}{ NIS } \\
\hline Russia & 0.6 & 10.9 & 8 & 11 & 27.0 & 48.3 & 1.7 & 38.7 \\
\hline Ukraine & 0.3 & 3.3 & $\ldots$ & $\ldots$ & 24.0 & 41.3 & 3.9 & 26.4 \\
\hline
\end{tabular}

Sources:

Col. 1,2,3 and 4: Boeri, 2000

Col. 5: Atkinson and Micklewright, 1992;

Col. 6: EBRD Transition Report 2001 ; Bulgaria, Russia and Ukraine -- 1996 values;

Col. 7 and 8: The World Bank, World Development Report 200/2001 ; Bulgaria - 1995; Romania - 1994; Russia - 1998 ; US - 1997. Notes:

Col. 3 and 4: The "Replacement Rate" is the average of gross replacement rates in 1992-1993, inclusive of social assistance for one-person in the first two years of employment, adjusted for inflation where indexing was applicable. It is taken as the share of 2 times the average wage and $2 / 3$ the average wage.

Col. 5 and 6: The "Gini" coefficients are calculated using monthly earnings data as reported by employers. Small employers are often excluded.

Col. 7: "P10" denotes the percentage share of income at the bottom (10th) decile.

Col. 8: "P90" denotes the percentage share of income at the top (90th) decile. 
Figure 1: Employment and Output Adjustment

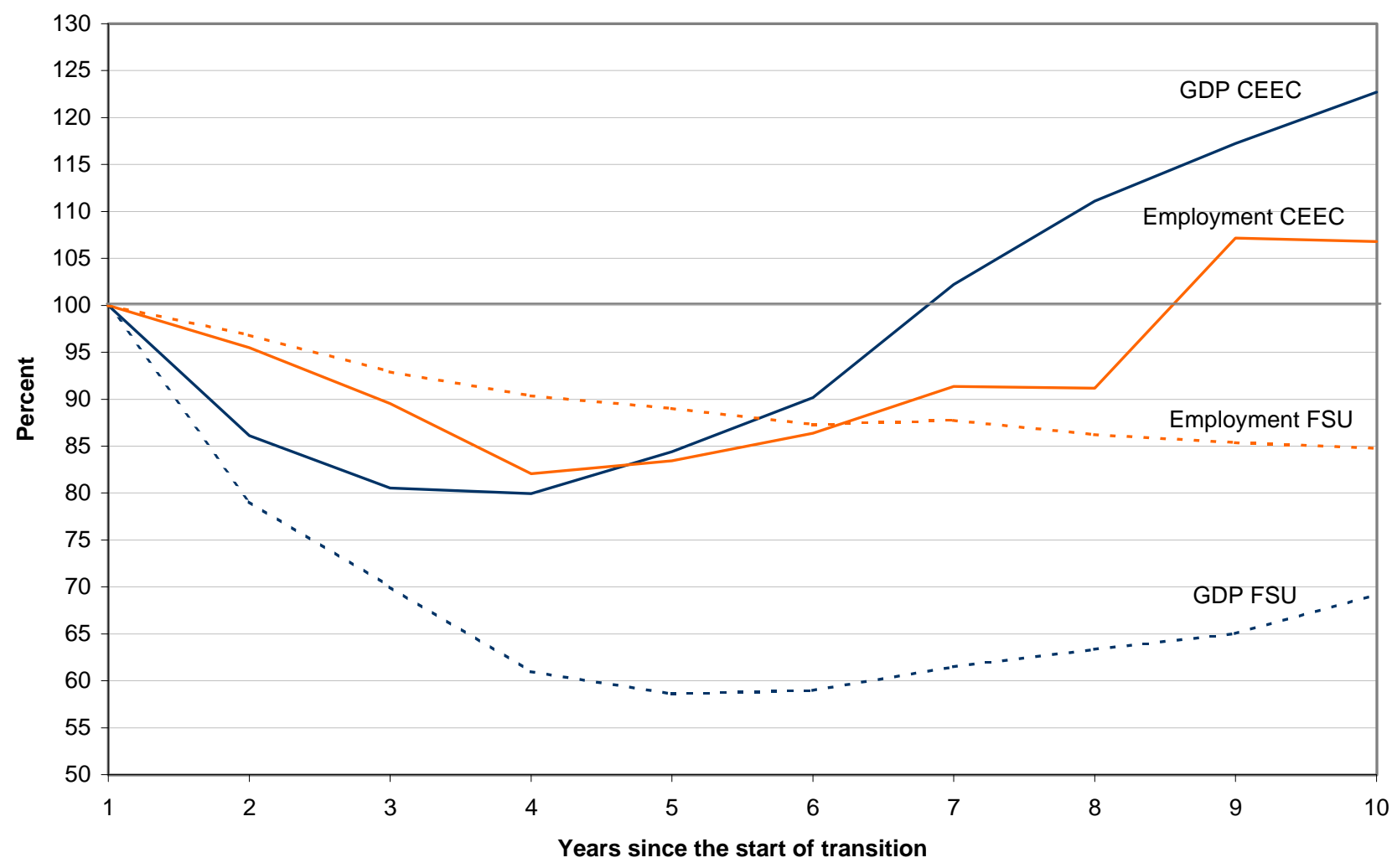

Notes: Unweighted Average, 1989=100 for Poland; 1990=100 for other CEECs (Central and Eastern European Countries); $1991=100$ for FSU (Former Soviet Union).

Source: EBRD, Transition Report 2000, Transition report update 2001. 
Figure 2: Real Wages (1989=100, adjusted by the CPI)

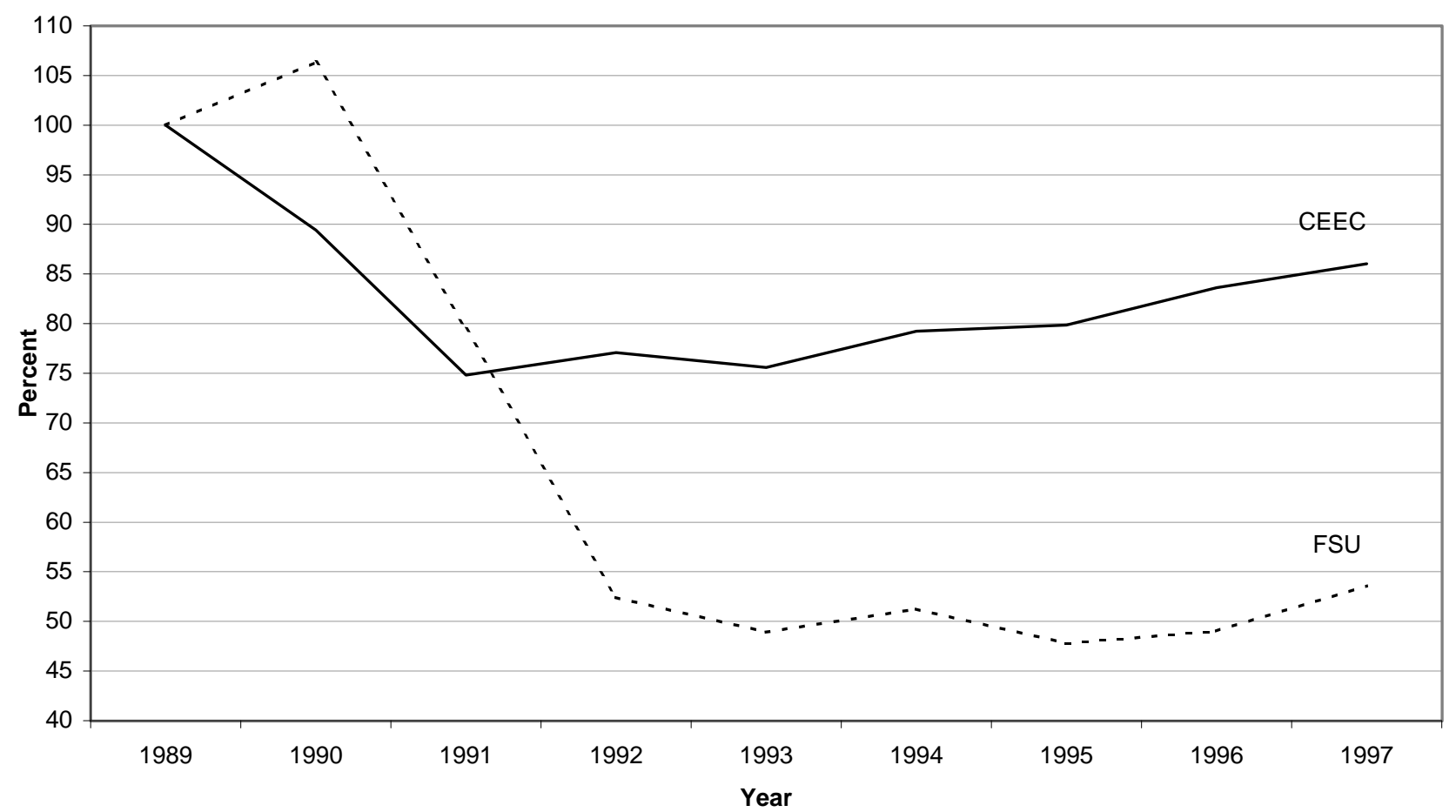

Note: Unweighted average; CEECs include the Czech Republic, Slovakia, Hungary and Poland; the FSU includes Estonia, Latvia, Lithuania and Russia.

Source: CEE/CIS/Baltics Regional Monitoring Report, 1999. 
Figure 3: Percentage Change in Enrolment Rates, 1989 - 1996

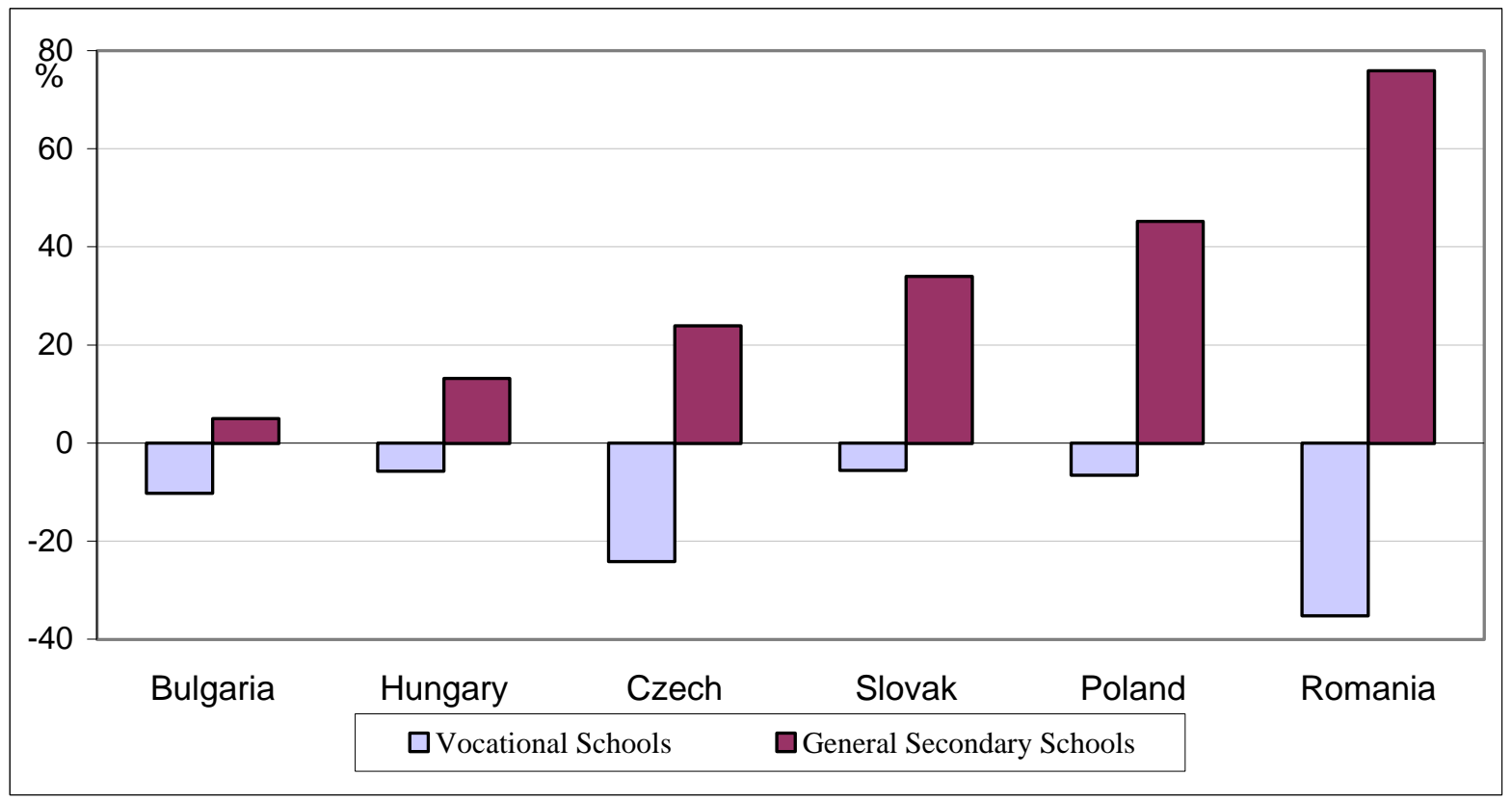

Source: Boeri, 2000. 
Figure 4: Minimum Wage as a Percent of Real Wage

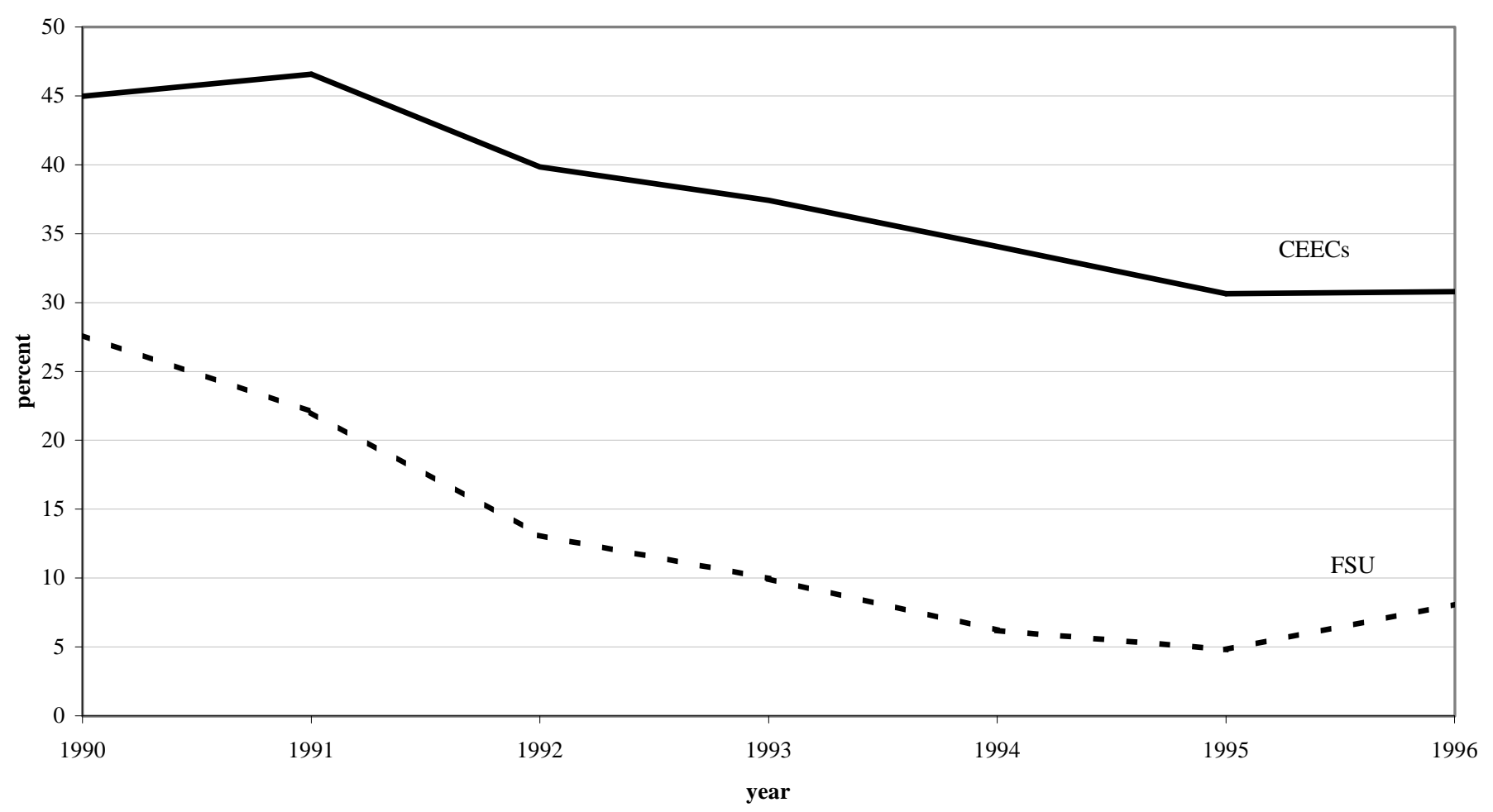

Note: Unweighted average; CEECs include Bulgaria, the Czech Republic, Hungary, Poland, Romania and Slovakia; FSU includes Russian and the Ukraine.

Source: Vaughan-Whitehead, 1998. 